1 Evolving integrated models from narrower economic tools: the example of forest sector models

2 Miguel RIVIERE ${ }^{\mathrm{a}, *}$, Sylvain CAURLA ${ }^{\mathrm{a}}$, Philippe DELACOTE ${ }^{\mathrm{a}, \mathrm{b}}$

$3{ }^{\mathrm{a}}$ : Université de Lorraine, Université de Strasbourg, AgroParisTech, CNRS, INRAE, BETA, 54000, Nancy, France

4 b: Climate Economics Chair, Univ. Paris Dauphine, Paris, France

$5 \quad$ *: Corresponding author: miguel.riviere@ agroparistech.fr. BETA, Campus AgroParisTech, 14 rue Girardet, 54042

$6 \quad$ Nancy cedex, France. +33383396858

7 ORCID:

- $\quad$ Miguel Riviere: 0000-0003-3469-9588

- Sylvain Caurla: 0000-0002-8785-7079

- $\quad$ Philippe Delacote: 0000-0002-9888-7193

\begin{abstract}
Integrated simulation models are commonly used to provide insight on the complex functioning of socialecological systems, often drawing on earlier tools with a narrower focus. Forest sector models (FSM) encompass a set of simulation models originally developed to forecast economic developments in timber markets, but now commonly used to analyse climate and environmental policy. In this paper, we document and investigate this evolution through the prism of the inclusion of several non-timber objectives into FSM. We perform a systematic, quantitative survey of the literature followed by a more in-depth narrative review. Results show that a majority of papers in FSM research today focuses on non-timber objectives related to climate change mitigation, namely carbon sequestration and bioenergy production. Habitat conservation, deforestation and the mitigation of disturbances are secondary foci, while aspects such as forest recreation and regulation services are absent. Nontimber objectives closest to the original targets of FSM, as well as those for which economic values are easier to estimate, have been more deeply integrated to the models, entering the objective function as decision variables. Others objectives are usually modelled as constraints and only considered through their negative economic impacts on the forest sector. Current limits to a deeper inclusion of non-timber objectives include the models' ability to represent local environmental conditions as well as the formulation of the optimisation problem as a maximisation of economic welfare. Recent research has turned towards the use of model couplings and the development of models at the local scale to overcome these limitations. Challenges for future research comprise extensions to other non-timber objectives, especially cultural services, as well as model calibration at lower spatial scales.
\end{abstract}

Keywords: forest sector model, forestry, economics, environmental modelling, ecosystem services, integrated assessment

JEL codes: C61, L7, Q21, Q23, Q57

\title{
Acknowledgements
}

This work was supported by the French Ministère de l'Agriculture et de l'Alimentation. The BETA contributes to the LabEX ARBRE ANR-11-LABX-0002-01. This research is part of the Agriculture and Forestry research program by the Climate Economics Chair. The authors want to thank the Climate Economics Chair for financial support. The authors want to thank Pr. Harold Levrel for his attentive help, as well as our anonymous reviewers for their insightful comments and suggestions. 
Human societies are today facing a wide array of complex environmental, social and economic challenges at the global scale, including but not restricted to, climatic changes, the erosion of biodiversity and transitioning to lowcarbon economies [1-3]. Addressing these challenges requires developing a comprehensive but thorough understanding of intricate social-ecological systems in order to perform so-called integrated assessments. These in turn often rely on integrated models, which must be able to incorporate ecological, biophysical, economic and social information and dynamics of the systems of interest [4-6]. Yet many such models were initially developed with a narrower focus, requiring changes to be made in order to expand the range of analyses possible. Such developments in turn raise questions concerning the suitability of models.

Among social-ecological systems, forests and forestry play a key role in addressing the above-mentioned issues. Forests cover around 30\% of land area globally and provide many market and non-market ecosystem goods and services [7-8]. Traditional forest objectives include the production of timber for construction or furniture as well as the manufacturing of paper, which support large industrial sectors. Forestry contributes to climate change mitigation through carbon sequestration [9] and energy or material substitution [10-11]. Forests provide regulation services such as erosion control, water purification, flood regulation and pollination, etc. [12-13], as well as cultural services such as recreation and hunting [14-15]. In addition, forests host a large share of the world's biodiversity and harbour key habitats [16]. These many goods and services are characterised by complex antagonistic or synergistic relationships at different spatial and temporal scales [7, 17], and while forest management often pursues timber production as its main objective, it also affects the provision of other goods and services [18].

The relationships between multiple forest management objectives have been studied with various methodologies. Traditional forest economics frameworks such as that of the optimal rotation problem [19] can be extended to account for multiple amenities [20], the joint production of several amenities can be studied by assessing production possibility frontiers [17], and the provision of multiple ecosystem services can be spatially evaluated with mapping tools [21-22]. Several techniques for forest planning have been developed based on group decision making, multi-criteria decision support or public participation [23-25], and forest owners' motives for owning and managing forests can also be analysed using survey methods based on theories in social and behavioural sciences [26]. Among these methodologies, Forest sector models (FSM) encompass a set of simulation tools commonly used for policy analysis in the field of forest economics, with a core focus on forecasting developments in timber production and wood products markets [27-28]. As coupled bio-economic models of timber markets, forest management and biological dynamics, FSM offer a broad overview of forestry and the forest sector, making them good candidates as integrated models able to "explore the linkages and feedbacks between different system components, including the social, economic and ecological implications of different natural or anthropogenic factors" [4].

To date, however, there is no detailed, quantitative analysis on how FSM apply to objectives other than the production of timber, in particular environmental objectives. Previous contributions have focused on model theory and development [27-30], or have discussed FSM applications from a broad perspective [28, 31, 32]. The objective of this paper is to fill this gap and investigate how and to what extent forest objectives other than timber production (hereafter, non-timber objectives) have been studied using FSM. In particular, we aim at demonstrating how a category of originally narrow models focused on economic analysis has gradually evolved to carry out research on environmental questions, and what challenges this trend towards integration implies. Our objective is twofold: first, we seek to identify which non-timber objectives have been studied in FSM research and to what extent. Second, we want to give an overview of research questions over time, and document and question the evolution of modelling approaches. We rely on the combination of two complimentary methods: a systematic literature review and a more in-depth narrative review. This allows us to provide a quantitative overview of the field as well as to focus on specific aspects through examples.

\section{Context and review methodology}


FSM are representations of the forest sector based on economic theory. They are mathematical models using sets of equations and mathematical objects to represent a system, as well as simulation models solved numerically due to their large size. They were developed in the 1970s as a new way to project developments in timber markets and have since then been used for policy analysis [27-28, 32]. We present an overview of FSM focusing on four aspects: the real-world target of FSM, their spatial format, their handling of temporal dynamics, and their objective function.

The real-world target of FSM is the forest sector, which is usually understood as comprising an upstream segment, forestry, and a downstream segment, forest industries [32]. Forestry encompasses forest resources, their biological dynamics (e.g., growth, mortality) and timber harvesting, while forest industries encompass the processing and transportation of wood products and their sale onto the market. The exact boundaries of the forest sector are not clearly defined, and models do not share the same exact targets. On the forestry side, the least detailed models do not describe the resource, or only as aggregated timber volumes, while more detailed models distinguish between several tree species, diameter classes, ownership categories and are spatially-explicit [33-34]. On the industry side, several market levels can be represented [35]. Most models include several products (e.g., roundwood and pulpwood), and many include a second level in transformed products (e.g., plywood, lumber.). Generalist models focus on traditional wood products used for construction, furniture and paper, while specialized models focus on specific industries such as wood chips [36] or biofuels [37]. FSM vary in their geographical scopes and spatial formats, and can be developed at the country [38-40], regional [41-42] or global levels [30-43]. Most models are spatialized and include several demand and supply regions, but a few are aspatial with a single region [44].

FSM are equilibrium models where market equilibrium is found by equating supply (quantity of timber produced) and demand (quantity consumed) for all products. The majority of models finds the so-called spatial price equilibrium [45] by solving a large mathematical programming problem where the sum of consumer and producer surpluses net of transport costs, or net social surplus (NSS), is maximised under a set of constraints ensuring nonnegativity of key variables and enforcing lower and upper bounds for some of them $[28,30]$. In a case with several products $k$ and regions $(i, j)$, NSS is equal for a given year $t$ to:

$N S S_{t}\left(D_{i k t}, S_{i k t}, e_{i j k t}\right)=\sum_{i} \sum_{k} \int_{0}^{D_{i k t}} P_{i k t}\left(D_{i k t}\right) d D_{i k t}-\sum_{i} \sum_{k} \int_{0}^{S_{i k t}} P_{i k t}\left(S_{i k t}\right) d S_{i k t}-\sum_{i} \sum_{j} \sum_{k} T C\left(e_{i j k t}\right)$,

where $D$ refers to quantities demanded, $S$ to quantities produced, $e$ to quantities transported between regions and $T C$ to transport costs (adapted from [30,46]). The term $\int_{0}^{D_{i k}} P_{i k}\left(D_{i k}\right) d D_{i k}$ corresponds to areas under demand curves (consumer surplus), the term $\int_{0}^{S_{i k}} P_{i k}\left(S_{i k}\right) d S_{i k}$ to areas under supply curves (producer surplus), and the term $T C_{i j k} e_{i j k}$ to transport costs.

FSM are usually separated into two categories based on their handling of time [47]. Intertemporal models assume agents have perfect foresight and solve all market equilibria at the same time. These models are well suited for long-term analyses [28]. On the opposite, recursive models assume limited foresight and solve equilibria one period at a time. They are made dynamic by recursively updating the model's parameters [30], and are better suited for short to medium-term analyses. In addition, some models are purely static [48]. In the case of a recursive model, the optimisation for a given year $t$ can be written as:

$\operatorname{Max}_{D_{i k t}, S_{i k t}, e_{i j k t}} N S S_{t}\left(D_{i k t}, S_{i k t}, e_{i j k t}\right)$

with rules on how parameters should be updated after each time period. For example, supply equations in the French Forest Sector Model [49] (FFSM) are given by:

$S_{i k t}=S_{i k t-1}\left(\frac{P_{i k t}}{P_{i k t-1}}\right)^{\alpha_{k}}\left(\frac{I_{i k t}}{I_{i k t-1}}\right)^{\beta_{k}}$

where $S_{i k t}$ and $P_{i k t}$ are supply and price for the current year respectively and $S_{i k t-1}$ and $P_{i k t-1}$ for the previous year. Similarly, $I_{i k t}$ is the available forest inventory (timber volume) in year $t$ and $I_{i k t-1}$ the available inventory the 
previous year. $\beta_{\mathrm{k}}$ and $\alpha_{\mathrm{k}}$ are the elasticities of supply to inventory and prices respectively. When the model is intertemporal, all equilibria are solved at the same time and the sum of discounted surpluses is maximised over the time horizon $T$ using discount rate $r$ :

$\forall t \in[0, T], \operatorname{Max}_{D_{i k t}, S_{i k t}, e_{i j k t}} \sum_{t=0}^{T}(1+r)^{-t} \operatorname{NSS}_{t}\left(D_{i k t}, S_{i k t}, e_{i j k t}\right)$,

131

The determination of quantities produced, consumed, traded and prices is endogenous. Elasticities are usually estimated econometrically or taken from the literature, and trade data (e.g., from the FAO) and forest inventory data (e.g., from national forest inventories) are used to calibrate the models. A small number of models do not follow the general framework described here. For example, the model developed by Schwarzbauer \& Rametsteiner [44] falls within the Systems Dynamics framework, where demand and supply are not determined simultaneously in an optimisation process, but oscillate around equilibrium values. For more details regarding FSM, the reader can refer, among others, to [28-30, 50].

\subsection{Non-timber objectives}

Forest management can be defined as "the integration of silvicultural practices and business concepts in such a way as to best achieve a landowner's objectives" [51]. The main objective pursued by landowners is usually timber production. This is illustrated by early works on optimal forestry practices such as that of Faustmann [19], where maximising returns from wood production is the key element. However, forest management can pursue several objectives in addition to the production of wood [52], and terms such as "multiple-use" or "multifunctional" are often encountered [52-54]. This multiplicity of potential objectives is recognised in the definition of "sustainable forest management" [55], and the FAO FRA database [56, 57] uses a classification of forestland according to their management objectives, illustrating the diversity of objectives that can be pursued (Table 1).

Table 1 Examples of forest management objectives and forest ecosystem services [56-58]

\begin{tabular}{|c|c|}
\hline FRA database classification & Krieger (2001) \\
\hline $\begin{array}{l}\text { Production of goods } \\
\text { - Industrial roundwood } \\
\text { - Fuelwood (bio-energy) } \\
\text { - Non-wood forest products }\end{array}$ & $\begin{array}{l}\text { Raw materials (including timber and non- } \\
\text { timber products) } \\
\text { Food production }\end{array}$ \\
\hline $\begin{array}{l}\text { Protection of soil and water } \\
\text { - Production of clean water } \\
\text { - Coastal stabilization } \\
\text { - Desertification control } \\
\text { - Avalanche control } \\
\text { - Erosion and flood protection } \\
\text { - Other purposes }\end{array}$ & $\begin{array}{l}\text { Water regulation } \\
\text { Water supply } \\
\text { Erosion control and sediment retention } \\
\text { Soil formation } \\
\text { Waste treatment } \\
\text { Nutrient cycling }\end{array}$ \\
\hline Conservation of biodiversity & Genetic resources \\
\hline $\begin{array}{l}\text { Provision of social services } \\
\text { - Public recreation (including hunting and } \\
\text { berry-picking) } \\
\text { - Carbon sequestration and storage } \\
\text { - Spiritual and cultural services }\end{array}$ & $\begin{array}{l}\text { Recreation (including general recreation and } \\
\text { hunting-fishing) } \\
\text { Cultural services (including heritage values, } \\
\text { aesthetics and endangered species habitats) }\end{array}$ \\
\hline
\end{tabular}

Climate regulation (including carbon sequestration)

\begin{tabular}{ll}
\hline $\begin{array}{l}\text { Multiple-use (several objectives with none } \\
\text { significantly more important than the others) }\end{array}$ & \\
\hline $\begin{array}{l}\text { Other (than production, protection, } \\
\text { conservation, social services and multiple use) }\end{array}$ & Biological control
\end{tabular}


Many objectives relate to the provision of ecosystem services, which can be broadly defined as "the direct and indirect contributions of ecosystems to human wellbeing" [59] and are often categorized as provisioning services, regulation services or cultural services [60]. To give an example, we included in Table 1 forest ecosystem services reviewed by Krieger [58] in their assessment of forest ecosystem values, but some classifications name up to 100 services [7]. Not all objectives fall under the scope of ecosystem services. Biodiversity conservation is often cited as a management objective, but biodiversity is usually considered not to be a service, rather a support for services, or even a good [61]. Other objectives are revealed when looking at individual owners' motivations for owning forests [62-66], and a short review reveals that some would be located further down the ecosystem services cascade and could be considered benefits (e.g., financial stability, passing on to the next generation). Because of the diversity in classifications and definitions, we chose to use the general term "non-timber objective" to refer to all finalities pursued by forest owners through forest management other than the production of timber.

\subsection{Review methodology}

160

161

162

163

164

165

166

167

168

169

170

171

172

173

174

175

176

177

178

179

We follow a two-step process, as illustrated in Figure 1. In the first step, we systematically gather scientific publications using Scopus database. A first search query aims at retrieving publications based on historically significant FSM, using the models' names and abbreviations for them. The list of FSM included in the query is based on publications on the development and history of FSM [27-29, 31]. A second search query uses keywords related to common denominations used to describe FSM, alongside keywords related to the forest sector and economics. This allows us to retrieve publications where other FSM are used. In order to sort articles obtained from the query, and in line with the literature [27-29, 32, 67], we narrow the definition of FSM to models (1) rooted in economic theory, (2) representing the forest sector, i.e., forestry plus forest industries, (3) at the sector scale, and (4) at a temporal scale relevant to forest-related questions (when models are dynamic). Publications where a multi-sector model is used are only considered when the forest sector is the main focus of the paper. These criteria lead us to exclude models at the individual owner or forest stand scale, and biological growth models.

Fig.1 Illustration of the review process: search queries used (left) and analysis of retrieved papers (right).

In a second step, we analyse publications in the review dataset. We perform standard bibliometric analyses and we carry out a bibliometric network analysis based on keyword co-occurrence using VOSviewer ${ }^{1}$ [68, 69]. Based on titles, abstracts and keywords (and, when necessary, full-texts), we identify papers dealing with non-timber objectives and identify which objectives are being investigated. In addition to this quantitative review, we perform a more in-depth narrative review. We give an overview of research questions (i.e., which aspects of non-timber objectives are being investigated?), review modelling approaches to the inclusion of non-timber objectives and identify current modelling trends.

\section{Systematic review and bibliometric analyses}

\subsection{Paper count and publishing dynamics}

The systematic review yields 248 publications. As shown on Figure 2, the amount of paper published annually has been increasing steadily, and since 2005 at least 9 papers have been published every year. As we conducted the review in July 2019, paper count for 2019 may still increase. We separated papers into two categories: analyses, where a model is used to answer a research question about the forest sector, and non-analyses, which comprise reviews, theoretical contributions and model presentations. We found 51 non-analyses and 197 analyses. Among analyses, $56(28 \%)$ did not consider a non-timber objective, and 141 (72\%) did. While the amount of papers considering timber production alone has stayed relatively constant over time, the amount of papers focused on

\footnotetext{
1 A co-occurrence link is formed between two keywords when they appear in the same publication. The more often keywords appear together, the stronger the link. Keywords and links are then represented on a network where distances between items indicate their level of relatedness, and items are further separated into clusters. Keywords whose spelling varies across publications are merged using a thesaurus.
} 
non-timber objectives has strongly increased in recent years. Since 2010, half or more of papers published every year have included non-timber objectives.

Fig.2 Distribution of reviewed papers per date of publication and thematic focus

As shown in Table 2, a few journals concentrate most papers. The most common are specialised forest economics journals (e.g., Forest Policy and Economics, Journal of Forest Economics) and generic forest sciences journals (e.g., Forest Science, Scandinavian Journal of Forest Research). Of lesser importance but still well represented are journals specialised in energy and climate issues (e.g., Energy Policy, Biomass and Bioenergy, Climatic Change) and resource economics journals (e.g., Agricultural and Resource Economics Review, Environmental and Resource Economics). Few papers are published in general economics journal (e.g., 1 and 2 papers in the American Economics Review and Applied Economics respectively) or modelling journals (e.g., Ecological Modelling and Environmental Modelling and Assessments both have two papers). The Scopus subject areas ${ }^{2}$ most represented are Agricultural and Biological Sciences (175 papers), Environmental Sciences (166), Social Sciences (74), Economics, Econometrics and Finance (67) and Energy (34).

We propose two possible explanations for these trends: (1) researchers in the field focus their publications on journals specialised in forestry (with a focus in economics or not) rather than journals that are more generic. This may be linked to the fact that, historically, forest sector modelling developed within an already specialised field, that of forest economics [50]; (2) more generic journals may have a low degree of openness to applied, forestrelated topics. Both explanations are a concern, given the wide environmental importance (climate change, biodiversity) that forests have for society.

In addition, we note the relative absence of modelling journals, which could indicate a focus in published papers on results and policy implications rather than on methods and modelling tools. In the papers we reviewed, those published in modelling journals were focusing on the development of new "modules" within already established models [33, 70, 71] or developed new models [72] and contained detailed information about model specifications. However, the vast majority of papers reviewed contained much less information: given the large size and complexity of FSM, details about modelling techniques are usually published as separate books or technical reports $[42,73]$.

Table 2 Bibliometric information about publishing journals (left) and authors' country affiliations (right).

\begin{tabular}{|c|c|c|c|}
\hline Journal & Paper count & Country & Paper count \\
\hline $\begin{array}{l}\text { Forest Policy and } \\
\text { Economics }\end{array}$ & 36 & United States & 131 \\
\hline $\begin{array}{l}\text { Journal of Forest } \\
\text { Economics }\end{array}$ & 22 & Norway & 40 \\
\hline $\begin{array}{l}\text { Scandinavian Journal of } \\
\text { Forest Research }\end{array}$ & 13 & Canada & 25 \\
\hline Forest Science & 12 & Finland & 24 \\
\hline $\begin{array}{l}\text { Canadian Journal of Forest } \\
\text { Research }\end{array}$ & 10 & France & 18 \\
\hline Energy Policy & 7 & New Zealand & 13 \\
\hline Forest Products Journal & 7 & Sweden & 11 \\
\hline Biomass and Bioenergy & 6 & Austria & 10 \\
\hline $\begin{array}{l}\text { Canadian Journal of } \\
\text { Agricultural Economics }\end{array}$ & 6 & Germany & 10 \\
\hline Journal of Forestry & 5 & Italy & 7 \\
\hline $\begin{array}{l}\text { New Zealand Journal of } \\
\text { Forestry Science }\end{array}$ & 5 & China & 6 \\
\hline
\end{tabular}

\footnotetext{
${ }^{2}$ A journal can belong to several categories, e.g., Forest Policy and Economics appears in both the Agricultural and Biological Sciences and Economics, Econometrics and Finance categories.
} 
Most of the research activity seems to take place in developed countries with large forest industries (and hence policy relevance), especially those where the research field originated and where research programmes are likely well established. As shown in table 2, the country most represented in authors' institutional affiliations is by far the United States, which is where a large part of FSM research started [28]. Besides, several models with regional, national and global scopes still in use today are being developed by US-based institutions [39, 73, 74]. European countries such as Sweden, France, Finland, Norway, Germany and Austria are also well represented. These all share the characteristic to have extensive forest areas and/or a large forest industry. Besides, one of the early clusters of model development was based at IIASA, an international research organisation located in Austria [28]. New-Zealand and Canada, which also possess significant forest sectors, are also well represented. Countries from other continents are almost absent, in particular countries with tropical forests, despite their environmental and economic relevance. Instead, most issues related to tropical forests (illegal logging mostly) appear in our review to be studied using global models developed in the USA or in Europe, with a focus on international trade [75-77], even when no authors are affiliated to these countries [78]. This point may be explained by the fact that most research related to tropical forests focus on land-use change and deforestation, issues that go beyond the scope of the forest sector alone. This implies that tropical forests are more likely to be treated trough land-use change models rather than FSM.

\subsection{Network analysis and identification of non-timber objective categories}

We report results from the bibliometric network analysis as a network of keywords in figure 3. Two clusters (A and D) comprise keywords associated with the production of timber and wood products. Cluster A has a stronger focus on forest industries and timber markets, illustrated by keywords such as "trade", "competition", "timber market" or "demand/supply", while cluster D has a stronger focus on forestry, with keywords such as "forest", "forest management" and "timber". Cluster B is associated with the production of renewable energy from woody biomass ("bioenergy", "biomass", "renewable energy/resource", "fossil fuel"), and cluster C is associated with forest carbon and climate change ("climate change", "carbon", "carbon sequestration", "land use change", "greenhouse gas"). Together, clusters B and C refer to the forest sector's contribution to climate change mitigation through energy substitution and carbon sequestration. Keywords referring to methods used, such as "forest sector model", "partial equilibrium model” or "computer simulation" are distributed among all clusters.

Fig.3 Bibliometric network analysis based on keyword co-occurrence (a), and temporal trends in keyword use (b). The size of items is proportional to the number of occurrences, and distances between items indicate their level of relatedness. For visibility purposes, we limited the display to the most common 105 keywords, which corresponds to at least 8 occurrences within the dataset, and only the 500 strongest links are displayed. In figure (a), keywords clusters are represented in different colours, while figure (b) displays the average year keywords were used in.

Based on the network analysis and our reading of papers, we identify 5 non-timber objectives in the papers reviewed: bioenergy production (59 papers), management for the regulation of risk associated to disturbances (12), climate change mitigation (45), habitat conservation (22), and water regulation (3). While the latter three correspond to forest management objectives identified in our introductory review, the former two were more delicate to define, and we detail the thought process behind our choice.

- We chose to consider bioenergy products separately from traditional wood products for three reasons. First, their inclusion in the FSM literature is recent and represents a significant amount of publications where the focus is on technology-intensive products. Second, in forest sciences, fuelwood production is often considered separately from regular timber or paper production. Third, papers often adopt a climate perspective based on energy substitution and avoided emissions, and we consider climate change mitigation to be a non-timber objective. However, we separate "bioenergy" papers from "climate change mitigation" papers because of their specialised and deep focus. The latter have a broader scope, while the former are in-depth analyses of bioenergy industries and their development potential. 
- Disturbances such as fires or storms affect the forest's ability to provide goods and services. In order to mitigate risks associated to these disturbances, managers may take actions they would otherwise no take (e.g., prescribed burning). Besides, disturbances affect both timber and non-timber objectives (e.g., habitats for biodiversity, carbon stored) and, in some cases, only affect non-timber objectives. For example, lowland Mediterranean forests produce little timber, but are heavily managed both at the stand and landscape levels to mitigate fire risks due to threats posed to biodiversity, recreational uses or human settlements [79]. In such a case, fire prevention can even become the main objective. Hence, we chose to consider the regulation of risks associated to disturbances as a separate non-timber objective.

While bioenergy production and climate change mitigation seem to correspond to keywords found in clusters B and $\mathrm{C}$ respectively, conservation, despite representing a large number of publications, did not emerge as a consolidated cluster. Instead, keywords such as "biodiversity" and "conservation" appear in cluster A, "deforestation" in cluster C, and other keywords such as "sustainability" or "ecosystem" only appear when adding less common keywords. FSM research on the topic may therefore be less structured or present a wider variety of research questions and keywords. Management for the regulation of disturbances and water services do not appear as consolidated clusters due to the smaller amount of papers. Some clear temporal trends can be identified: the use of keywords in cluster B (bioenergy-related) is more recent, and the use of keywords in cluster D (forestry-related) is more ancient. $90 \%$ of bioenergy studies, $60 \%$ of climate change mitigation studies and $46 \%$ of conservation studies were published after 2010. Climate change mitigation and especially bioenergy production seem to be recent topics, while conservation has been a longer-term, albeit minor focus in the literature. Bioenergy production is the most important non-timber focus in FSM research today, accounting for 37\% of publications since 2010.

\subsection{How does the inclusion of non-timber objectives affect the models?}

The inclusion of a non-timber objective requires the model to be able to quantify, in biophysical or monetary units, the realisation of that objective. If a goal is set for the production of a non-timber good or service (i.e., a certain amount is to be reached), the objective needs to enter decision rules, that is to say, the optimisation problem. Since the objective function in FSM is an economic surplus, only non-timber objectives for which an economic value can be estimated in monetary units can enter the objective function directly. When no monetary value exist, nontimber objectives usually enter the optimisation problem through constraints to the maximisation of net social surplus. Besides, when the level of non-timber objective is to be determined endogenously, a new decision variable needs to be added to the maximisation problem. In cases where the model does not hold the information needed to perform quantification endogenously, a model coupling can be established, where specialised models are used exogenously, and perform calculations from FSM outputs.

We illustrate this with a commonly introduced non-timber objective, in-situ carbon sequestration, i.e., in forests. The first step of any inclusion of carbon sequestration into FSM is the quantification of carbon stocks and fluxes. To achieve this goal, many modellers have opted for the development of "carbon accounting modules", i.e., registries where amounts of carbon stored in several compartments are tracked over time [39, 80-81]. Because carbon quantities are directly linked to forest biomass, these accounting modules rely on forest inventory submodels already present in most FSM and use expansion factors to convert cubic meters of wood to tons of carbon. Wear and Coulston [67] provide a detailed overview of the main assumptions behind forest inventory modules used to project carbon dynamics in FSM. Alternatively, the description of forest resources within some FSM may be too aggregated to allow for a good conversion to carbon contents. In this case, specialised ecological models can be mobilised, as in Kallio et al. [82], where FSM outputs are used as inputs to a forest stand growth simulator where the development of forest biomass and carbon stocks is simulated with more accuracy.

Then, the inclusion of carbon sequestration into FSM can take two routes. Firstly, it can be introduced as an objective through monetisation and subsequent addition to the objective function. A price is given in monetary units per ton of carbon, many estimates being available in the literature [2]. Landowners receive a yearly payment equal in year $t$ to $P_{c, t}\left(\Delta C_{t}-\Delta C_{t}^{B A U}\right)$, where $P_{c, t}$ is the price of carbon in year t, $\Delta C_{t}$ the change in carbon stock 
between years $\mathrm{t}$ and $\mathrm{t}-1$, and $\Delta C_{t}^{B A U}$ the stock change in a baseline scenario ${ }^{3}$. Hence, the sum $\sum_{t=0}^{T}(1+r)^{-t} P_{c, t}\left(\Delta C_{t}-\Delta C_{t}^{B A U}\right)$ of payments received by landowners over a period $T$ can be directly added to NSS in the objective function in equation (4) (e.g., [83-85]). In the case of recursive models, the supply function is modified to account for the opportunity cost to harvesting due to carbon payments which acts as a tax, e.g. equation (3) becomes:

$S_{i k t}=S_{i k, t-1}\left(\frac{P_{i k t}-\omega_{k} P_{c, t}}{P_{i k, t-1}-\omega_{k} P_{c, t-1}}\right)^{\alpha_{k}}\left(\frac{I_{i k t}}{I_{i k, t-1}}\right)^{\beta_{k}}$,

where $\omega_{k}$ is the carbon density of product $\mathrm{k}$, and $\omega_{k} P_{c, t}$ represents the foregone carbon payment due to timber being extracted from the forest. Carbon payments themselves need to be added to producer surplus ex-post [8687]. In most applications, carbon sequestration is assumed to be an objective pursued on all forestland. However, in Latta et al. [85], the model endogenously determines land where this objective is to be pursued, and the amount of land enrolled in the carbon sequestration programme is introduced as a decision variable in equation (4).

Secondly, when carbon sequestration objectives are not included in the objective function, they can be introduced as constraints to the maximisation of net social surplus. In Im et al. [88], this takes the form of a constraint on carbon fluxes within the forest sector:

$\sum_{t=0}^{T}(1+r)^{-t}\left[\Delta C_{t}^{f}+\Delta C_{t}^{p}\right] \geq T_{\text {min }}^{C}$

where $\Delta C_{t}^{f}$ and $\Delta C_{t}^{p}$ are changes in carbon stocks in the forest and products pools respectively, discounted by discount rate r, and $T_{\min }^{C}$ is the carbon flux target over period $T$. Alternatively, due to the direct relationship between timber volume and carbon quantities, the constraint can be set as an upper limit to timber harvests [88-90]. In the next section, these various approaches are reviewed for each category of non-timber objective.

\section{Narrative analysis: research questions and the limits to integrating non-timber objectives}

\subsection{Research questions and transversal issues}

FSM were originally developed as market models to perform economic analysis. As illustrated by the high number of papers focusing on non-timber objectives, they have gradually become tools for environmental assessment as well. However, many non-timber objectives are only studied insofar as they affect economic activity and timber production, while others such as bioenergy production are more deeply integrated. We illustrate this fact by giving an overview of research questions and modelling approaches for each non-timber category.

Bioenergy papers largely aim at assessing the potential to develop bioenergy industries, their ability to reach renewable energy targets and implications for traditional timber industries [76, 91-93]. A strong focus is put on assessing the effectiveness of economic policy measures such as subsidies to bioenergy production or consumption [94-96]. Even though the early focus was on bioenergy markets themselves, recent contributions to the topic are increasingly concerned with the environmental footprint of bioenergy products, and deal with issues such as carbon neutrality [96-97], carbon stocks and land-use patterns [98-100] and implications for landscapes and habitats [101103]. Conversely, several contributions in the conservation category investigate the impacts of bioenergy policy [104-105]. The integration of bioenergy is the one we believe to be the deepest, owing to the fact that bioenergy production is easily quantifiable in both physical and monetary units the same way as regular timber products, i.e., with a market model assigning prices to quantities produced. In addition, bioenergy products (e.g., pellets,) are already traded on markets, and data is accessible to calibrate models. Hence, bioenergy production is often introduced as an endogenous objective in models, and quantities produced are decision variables. In some cases, energy demand is constrained to account for exogenous renewable energy production targets.

\footnotetext{
${ }^{3}$ In some cases, all carbon sequestered is subsidized, and the $\Delta C_{t}^{B A U}$ term equals 0 .
} 
Papers on climate change mitigation focus on two broad research questions. First, 13 papers seek to inform general forest policy by evaluating the impacts of climate change on timber markets, industries and forest resources [106108]. Second, 32 papers investigate the climate mitigation potential of the forest sector and seek to evaluate the costs and effectiveness of mitigation policies and strategies. Most of these papers include quantification of carbon fluxes, and rely on the use of the aforementioned carbon accounting modules, conversion factors or external models to do so. Carbon pricing is a straightforward and established economic method to assign monetary values to carbon stored and avoided emissions [109], allowing for a good integration to FSM. Indeed, 20 papers rely on carbon pricing, either payments for sequestration in forests [86-87, 110], or sector-wide carbon tax-subsidy schemes [111-112]. Carbon prices are usually set by the user, with some exceptions where carbon prices are endogenously determined [113-114]. Other approaches include setting constraints to the optimization in terms of harvest levels [89-90], and more rarely, carbon fluxes [88], eschewing monetization. Some models include the area committed to sequestration as a decision variable [115].

Other non-timber objectives are less deeply integrated. Most conservation papers seek to assess tradeoffs between economic activity and habitat conservation, usually quantified in loss of economic surplus or reduced timber supply [40, 104-105, 116-117]. Several papers focus on tradeoffs in deforestation-prone areas [77, 118-119] and three papers assess the economic implications of barriers to the trade of illegal timber $[75,78,120]$. In most cases, conservation does not enter the objective function, is not modelled explicitly and is introduced through constraints to the optimization problem, i.e., land is removed from production, harvest levels or traded quantities are constrained as proxies for conservation practices. Noteworthy exceptions in the sample include Kallio et al. [46] and Schleupner and Schneider [121], where the location of land to be conserved is a decision variable. Similarly, two papers on water services follow a constraint-based approach where forests around streams cannot be harvested [122-123]. The topic of disturbances revolves around three issues: pests and diseases (7 papers), forest fires (3), and storms (2); they are approached through the economic cost and sectoral impacts of prevention measures or $e x$ post recovery plans [124-130]. Only a few papers quantified the impacts of forest policy on habitat quality [103, 131], and one paper quantifies water quality and quantity implications of climate mitigation policies [132]. They rely on specialized exogenous models, e.g. habitat suitability or hydrology models.

Overall, examples of non-timber objectives included in the objective function encompass carbon sequestration, through carbon pricing, and bioenergy production, through market prices and econometrically estimated supply and demand functions. Examples are rarer for other objectives, which are most often only quantified in biophysical units, and either do not enter decision rules or as constraints to the optimisation problem. Some non-timber objectives are notably lacking from our sample. Forest recreation and more generally cultural services are absent, while it is an important topic in the ecosystem services literature [15]. Management for the provision of regulation services is limited to those that directly affect the economic profitability of forest activities, such as pests, fires and storms, and only three papers deal with water services.

Natural processes within forestry, especially those related to disturbances, are characterised by a high level of uncertainty [16]. Other uncertainties concern the evolution of prices, trade patterns, as well as parameters estimated for the models [133]. FSM are deterministic models, and uncertainties are traditionally treated by performing sensibility analyses [134]. However, we witnessed that the introduction of uncertainty constitutes a recent, albeit minor focus in FSM research. Three papers use probabilistic approaches such as Monte-Carlo simulation to account for uncertainty [133, 135-136], and one paper is a review dedicated to uncertainty [134]. Other recent contributions focus on re-estimating parameters and assessing the reliability of international databases used for model calibration [137-139].

\subsection{Modelling trends and implications}

As a consequence of the strong focus on non-timber objectives in recent years, we identify three emerging modelling trends, and discuss the challenges associated to each of them.

First, owing to the strong focus on bioenergy and climate issues, many FSM have become specialised models. some models have been developed for specific bioenergy markets [36-37]. This implies an increase in model 
complexity: models must be able to accurately represent biomass feedstocks, processing technologies and energy demand, and require data for model calibration that is both reliable and readily available. For example, the model in Tromborg et al. [140] includes 12 bio-heating technologies and 3 types of biomass from 6 different feedstocks in addition to conventional wood products and industries. Many models have been enhanced to include the abovementioned carbon accounting modules: these rely on assumptions regarding the carbon content of biomass and harvested wood products, their decay over time, and require information on GHG emissions from various processes as well as substitution coefficients to estimate avoided emissions. Such analyses entail the use of life-cycle-analysis or other methods to assess parameters, on which uncertainties remain [11,97]. A parallel trend is well-documented for Integrated Assessment Models (IAM) of the energy-climate system which are commonly used to evaluate climate policy. In recent years, many so-called hybrid IAM have been developed, which embed a detailed description of energy-producing technologies within a general top-down aggregated framework [141-142]. Such models face challenges in terms of computational requirements and complexity, theoretical consistency and empirical validity, as well as policy relevance [143]. This last point is of particular importance. Many FSM have become close to biomass-for-bioenergy supply chain models which are increasingly used to investigate the development potential of bioenergy industries and design supply chains at local scales and on generally shorter time horizons [144-145]. While methods and the study object are similar, modellers should keep in mind that despite potential similarities, different models are built to answer different questions. The focus in FSM research should stay on assessing energy policy in the forest sector from a broad, social planner perspective, in particular concerning the articulation with other objectives, traditional timber industries and the availability of forest resources. While this does not exclude technical refinements necessary to an accurate representation of bioenergy production, it entails finding a balance between model complexity and system completeness.

Second, the assessment of many non-timber objectives requires detailed, spatially explicit data on environmental conditions. Many FSM were originally developed at the global and national scales, and use aggregated data. We witnessed in our sample a recent trend towards the development of new models with restricted geographical scopes, or the downscaling of already existing models to lower spatial scales. For example, a spatially explicit version of the FFSM was developed from the national model in order to account for variability in environmental conditions [70], and a subnational module was developed for the USA for the Global Forest Products Model [146]. Several new models were created for individual Canadian provinces [147-148], as well as for the Scandinavian region [37]. Several papers we reviewed use Geographical Information System software [121, 149], and the newly developed LURA model uses plot-level forest data and individual plant-level data to produce a very spatially disaggregated model [150]. While earlier studies had to rely on ad-hoc criteria and proxies to model objectives such as conservation, this new generation of FSM is better equipped to handle non-timber objectives. Consequently, we expect the modelling of non-timber objectives to improve as these models develop, and we expect an increasing amount of studies focusing on non-timber objectives, including those still missing today. However, global and national models remain well-equipped to handle issues such as leakages or international trade distortions, and for this reason should not be abandoned [87, 90].

Third, many modellers have turned to the use of other, specialised models, coupling them to FSM in order to compensate for their weaknesses and expand the range of analyses possible. The most common type of coupling is established with models in environmental sciences. These include general circulation models to account for climate change [43, 151], landscape succession [101] or habitat quality models [46, 131] to account for environmental impacts, or forest growth simulators and soil models to calculate carbon fluxes [88, 152]. Another common linkage established is with energy models [153] or IAM [113], which is an alternative to the specialisation of FSM described earlier. Our sample also included the use of model couplings to study regulation services, for example with spread models for pathogens [71] or hydrology models [132]. This trend to develop "Economic Environment Integrated Models" is documented in the wider environmental modelling field, and is a welcome development since it enables performing new analyses [154]. However, it also increases complexity for modellers, who are required to ensure compatibility between models in terms of data requirement and their main assumptions. Besides, most couplings are established between a market model (FSM) and models in environmental sciences. While results are more comprehensive with regards to the multiple facets of forestry, interdisciplinary research is not without challenges, which can be both structural and conceptual in nature and should be taken into account when designing research projects $[155,156]$. 
448 FSM were originally developed to deal with topics related to timber production and trade at the national and progressively gone beyond their initial purpose by including non-timber objectives related to environmental issues. However, their core structure and target remain the same, which may hinder the investigation of some environmental goals and ecosystem services. The production of bioenergy and carbon sequestration, both contributing to climate change mitigation, are widely studied with FSM. Both objectives relate directly to the original purpose of FSM: projecting timber products supply (in this case, energy products) and projecting forest inventories, and their inclusion only required marginal changes to be made (e.g., estimating new econometric functions, converting timber volumes to carbon, using carbon prices). On the other hand, direct relationships between objectives such habitat conservation or forest recreation and timber inventories or markets are harder to establish, and their full inclusion would require significant changes.

Investigating such non-timber objectives often requires modelling the forest sector and forest resources at the local or sub-regional levels. Biophysical and economic assessment studies for many regulation and cultural services often rely on fine scale, spatially explicit data, such as the presence of recreation equipment, landscape viewpoints, topographic data at the local scale, etc. [157]. Even though many FSM are spatialized, they are so at more aggregated levels (e.g. regions) and are ill equipped to handle such information. Modelling such objectives also entails the inclusion of specific management practices (e.g., continuous-cover, close to nature forestry, etc.) as well as releasing the representative economic agent assumption to better represent heterogeneity in behaviours and preferences regarding environmental objectives. FSM were not originally developed to face such challenges, and even when technical refinements are made, data is often lacking to calibrate models such as [33, 70, 158]. Besides, the objective function of most FSM is an economic surplus, which requires non-timber objectives to be monetized and consequently hampers the inclusion of those for which monetary values are hard to estimate. Assessing the economic value of regulation services not linked to markets, and of most cultural services, remains elusive [159]. As a consequence, objectives in FSM are often modelled at two levels: some as constraints, others as decision variables within the optimization problem, which implies the precedence of some objectives on others. In some cases, objectives are not quantified, and significant simplifications are made to model objectives located further away from FSM's original targets (e.g., limits on harvests as a proxy for habitat conservation).

To improve the integration of non-timber objectives in FSM, future research should focus on building reliable databases of local environmental and economic conditions from which models can be calibrated. Research may also benefit from additional information regarding forest owners' attitudes towards non-timber objectives and their inclusion within traditional forest management practices. Such information could be obtained through surveys, focus groups or laboratory experiments, which also presents the advantage of anchoring research within a stakeholder-oriented dynamic. Once such information is available, an interesting direction to explore is that of Agent-Based Models (ABM). ABM are bottom-up models where dynamics at the system level arise from the combination of and interactions between multiple, individual agent-level decisions. Like traditional FSM, ABM can be based on both economic theory and empirical data, but may be better suited to the investigation of complex social-ecological systems with a high degree of heterogeneity [160-162]. Following the first steps made by Lobianco et al. [33] and Pohjola et al. [163], we believe such a direction could improve the modelling of environmental and behavioural diversity in FSM.

Regarding models themselves, the representation of forest resources is of particular importance. While many FSM are able to quantify the resource using multiple strata (e.g., diameter classes, ownership categories, etc.), little attention has been paid to the spatial organization of this resource. Moving from a volume-based description of forest inventories to a landscape-based approach could improve the models' ability to investigate non-timber objectives, in particular those related to regulation and cultural ecosystem services as well as biodiversity. Future efforts could also focus on reformulating the objective function as a multi-objective function where all objectives are integrated in a similar way, and where biophysical units can be used. For example, Yousefpour et al. [164] follow a goal programming approach and use a multi-objective function composed of the Net Present Value for commercial timber production and of carbon sequestration fluxes, to which different weights are attributed. Such 
multi-objective methods are commonly used in applied forest management [165], and could be developed within and benefit the FSM research field and allow for the inclusion of objectives for which the evaluation of economic value in monetary units is the main limitation.

Finally, we have demonstrated that, while FSM research has gone well beyond its original purpose and now routinely addresses climate and environmental issues, publishing dynamics remain centred on specialized journals. Given the current state and orientation of FSM research, as well as the significant importance held by forests in addressing global issues such as climate change and biodiversity erosion, we can only but encourage scholars in the field to communicate their results and methods to the wider environmental and natural resource management modelling field.

\section{Conclusions}

In this paper, we set out to document and investigate how a particular type of economic simulation models, Forest Sector Models, had been applied to investigate objectives other than their original focus, timber production. Results reveal that FSM have been increasingly used in the last thirty years to investigate environmental objectives. While early applications were dedicated to projecting timber supply and developments in wood products markets, the majority of papers today is concerned with climate change mitigation, through the production of bioenergy and/or carbon sequestration. Biodiversity conservation, the management of disturbances and water regulation services are secondary foci in FSM research, while aspects related to other regulation services and cultural services are absent. We also found out that FSM research has predominantly focused on non-timber objectives that only required marginal changes to be brought to the models. Indeed, while bioenergy production and carbon sequestration directly relate to the original purpose of FSM, e.g., projecting timber supply and timber inventories respectively, modelling objectives such as biodiversity protection or the provision of water services requires the use of spatially explicit data on environmental conditions. Besides, most FSM use total economic surplus as their objective function, which hinders the inclusion of objectives where an economic value in monetary units is hard to estimate. Objectives less commonly studied are often included as constraints to the optimization problem and do not become decision variables, are considered through their negative economic impacts on timber production, or their dynamics are significantly simplified. These approaches assume precedence of some objectives on others, and lead to the exclusion of many non-market benefits associated to ecosystem services. In recent years, research in the field has turned to the development of models with restricted geographical scopes in order to better take into account local conditions, as well as to the establishment of couplings with specialized models (e.g., ecological, hydrology, energy models etc.) which enable a more comprehensive and realistic representation of non-timber objectives. While these developments expand the range of analyses that can be performed with FSM and enable overcoming some of the abovementioned limitations, they also increase model complexity, entail the use of additional data for calibration, and require researchers to perform multidisciplinary research and to ensure the consistency and compatibility of the various methods used. 


\section{References}

[1] V. Masson-Delmotte et al., "Global warming of $1.5^{\circ} \mathrm{C}$ An IPCC Special Report on the impacts of global warming of $1.5^{\circ} \mathrm{C}$ above pre-industrial levels and related global greenhouse gas emission pathways, in the context of strengthening the global response to the threat of climate change, sustainable development, and efforts to eradicate poverty Summary for Policymakers Edited by Science Officer Science Assistant Graphics Officer Working Group I Technical Support Unit,” Geneva, 2018.

[2] J. Rogelj et al., "Mitigation Pathways Compatible with $1.5^{\circ} \mathrm{C}$ in the Context of Sustainable Development," in Global Warming of $1.5^{\circ} \mathrm{C}$. An IPCC Special Report on the impacts of global warming of $1.5^{\circ} \mathrm{C}$ above pre-industrial levels and related global greenhouse gas emission pathways, in the context of strengthening the global response to the threat of climate change, [MassonDelmotte, S. C. V., P. Zhai, H.-O. Pörtner, D. Roberts, J. Skea, P.R. Shukla, A. Pirani, W. Moufouma-Okia, C. Péan, R. Pidcock, and and T. W. (eds. . J.B.R. Matthews, Y. Chen, X. Zhou, M.I. Gomis, E. Lonnoy, T. Maycock, M. Tignor, Eds. In press, 2018.

[3] S. Diaz et al., "Summary for policymakers of the global assessment report on biodiversity and ecosystem services of the Intergovernmental Science-Policy Platform on Biodiversity and Ecosystem Services-ADVANCE UNEDITED VERSIONMembers of the management committee who provid," 2019.

[4] S. H. Hamilton, S. Elsawah, J. H. A. Guillaume, A. J. Jakeman, and S. A. Pierce, "Environmental Modelling \& Software Integrated assessment and modelling: Overview and synthesis of salient dimensions," Environ. Model. Softw., vol. 64, pp. 215-229, 2015.

[5] H. Van Delden, R. Seppelt, R. White, and A. J. Jakeman, "A methodology for the design and development of integrated models for policy support," Environ. Model. Softw., vol. 26, no. 3, pp. 266-279, 2011.

[6] G. Harris, "Integrated assessment and modelling : an essential way of doing science 1," Environ. Model. Softw., vol. 17, pp. 201207, 2002.

[7] L. J. Aznar-Sánchez, José A Belmonte-Ureña, M. J. López-Serrano, and J. F. Velasco-Muñoz, "Forest Ecosystem Services: An Analysis of Worldwide Research," forests, vol. 9, pp. 1-19, 2018.

[8] H. Tian et al., "Global patterns and controls of soil organic carbon dynamics as simulated by multiple terrestrial biosphere models: Current status and future directions," Global Biogeochem. Cycles, vol. 29, no. 6, pp. 775-792, 2015.

[9] R. A. Sedjo and B. Sohngen, "Carbon Sequestration in Forests and Soils," Ssrn, 2012.

[10] E. Eriksson et al., "Integrated carbon analysis of forest management practices and wood substitution," Can. J. For. Res., vol. 37, no. 3, pp. 671-681, Mar. 2007.

[11] H. K. Sjølie and B. Solberg, "Greenhouse gas emission impacts of use of Norwegian wood pellets: a sensitivity analysis," Environ. Sci. Policy, vol. 14, no. 8, pp. 1028-1040, Dec. 2011.

[12] R. N. Sturrock et al., "Climate change and forest diseases," Plant Pathol., vol. 60, no. 1, pp. 133-149, Feb. 2011.

[13] S. Broadmeadow and T. R. Nisbet, "The effects of riparian forest management on the freshwater environment: a literature review of best management practice," Hydrol. Earth Syst. Sci., vol. 8, no. 3, pp. 286-305, 2010.

[14] A. I. Milcu, J. Hanspach, D. Abson, and J. Fischer, "Cultural ecosystem services: A literature review and prospects for future research," Ecol. Soc., vol. 18, no. 3, p. art44, Sep. 2013.

[15] M. Hernández-Morcillo, T. Plieninger, and C. Bieling, "An empirical review of cultural ecosystem service indicators," Ecological Indicators, vol. 29. Elsevier, pp. 434-444, 01-Jun-2013.

[16] M. Hanewinkel, S. Hummel, and A. Albrecht, "Assessing natural hazards in forestry for risk management: A review," European Journal of Forest Research, vol. 130, no. 3. pp. 329-351, 2011.

[17] S. Garcia, J. Abildtrup, and A. Stenger, "How does economic research contribute to the management of forest ecosystem services?," Ann. For. Sci., vol. 75, no. 2, p. 53, 2018.

[18] P. Duncker et al., "How Forest Management affects Ecosystem Services, including Timber Production and Economic Return: Synergies and Trade-Offs," Ecol. Soc., vol. 17, no. 4, p. art50, Dec. 2012.

[19] FAUSTMANN and M., "Berechnung des Werthes, welchen Waldboden, sowie noch nicht haubare Holzbestande fur die Waldwirthschaft besitzen [Calculation of the value which forest land and immature stands possess for forestry]," Allg. Fotst- und Jagd-Zeitung, vol. 25, pp. 441-455, 1849

[20] R. Hartman, "THE HARVESTING DECISION WHEN A STANDING FOREST HAS VALUE," Econ. Inq., vol. XIV, no. March, pp. 52-58, 1976

[21] L. Tardieu, "The need for integrated spatial assessments in ecosystem service mapping," Rev. Agric. Food Environ. Stud., vol. 98, no. 3, pp. 173-200, 2017.

[22] J. Maes et al., "Mapping ecosystem services for policy support and decision making in the European Union," Ecosyst. Serv., vol. 1, no. 1, pp. 31-39, Jul. 2012.

[23] L. Diaz-Balteiro and C. Romero, "Making forestry decisions with multiple criteria: A review and an assessment," Forest Ecology and Management, vol. 255, no. 8-9. Elsevier, pp. 3222-3241, 15-May-2008.

[24] B. Uhde, A. Hahn, V. C. Griess, and T. Knoke, "Hybrid MCDA Methods to Integrate Multiple Ecosystem Services in Forest Management Planning: A Critical Review," Environ. Manage., vol. 56, no. 2, pp. 373-388, Aug. 2015.

[25] M. Buchy and S. Hoverman, "Understanding public participation in forest planning: a review," For. Policy Econ., vol. 1, no. 1, pp 15-25, May 2000.

[26] A. Ficko, G. Lidestav, Á. Ní Dhubháin, H. Karppinen, I. Zivojinovic, and K. Westin, "European private forest owner typologies: A review of methods and use," Forest Policy and Economics, vol. 99. Elsevier, pp. 21-31, 01-Feb-2019.

[27] D. M. Adams and R. W. Haynes, Resource and market projections for forest policy development : twenty-five years of experience with the U.S. RPA timber assessment. Springer, 2007.

[28] G. S. Latta, H. K. Sjolie, and B. Solberg, "A review of recent developments and applications of partial equilibrium models of the forest sector," J. For. Econ., vol. 19, no. 4, pp. 350-360, Dec. 2013.

[29] S. Northway, G. Q. Bull, and J. D. Nelson, "Forest sector partial equilibrium models: Processing components," For. Sci., vol. 59, no. 2, pp. 151-156, Apr. 2013.

[30] J. Buongiorno, "Global modelling to predict timber production and prices: The GFPM approach," Forestry, vol. 88, no. 3, pp. 291$303,2014$.

[31] A. Toppinen and J. Kuuluvainen, "Forest sector modelling in Europe-the state of the art and future research directions," For. Policy Econ., vol. 12, no. 1, pp. 2-8, 2010.

[32] B. Solberg, "Forest sector simulation models as methodological," Silva Fennica, vol. 20, no. 4. pp. 419-427, 1986.

[33] A. Lobianco, P. Delacote, S. Caurla, and A. Barkaoui, "Accounting for Active Management and Risk Attitude in Forest Sector Models An Impact Study on French Forests,” Env. Model Assess, vol. 21, pp. 391-405, 2016. 
[34] H. K. Sjølie, G. S. Latta, T. Gobakken, and B. Solberg, "NorFor - a forest sector model of Norway Model overview and structure," INA fagrapport 18. Department of Ecology and Natural Resource Management Norwegian University of Life Sciences. 2011.

[35] C. Johnston and G. C. van Kooten, "Modelling Bi-lateral Forest Product Trade Flows : Experiencing Vertical and Horizontal Chain," no. August, 2014

[36] A. M. I. Kallio, P. Anttila, M. McCormick, and A. Asikainen, "Are the Finnish targets for the energy use of forest chips realisticAssessment with a spatial market model," J. For. Econ., vol. 17, no. 2, pp. 110-126, 2011.

[37] W. F. Mustapha, E. Trømborg, and T. F. Bolkesjø, "Forest-based biofuel production in the Nordic countries: Modelling of optimal allocation," For. Policy Econ., no. September 2016, pp. 1-10, 2017.

[38] S. Caurla, P. Delacote, F. Lecocq, J. Barthès, and A. Barkaoui, "Combining an inter-sectoral carbon tax with sectoral mitigation policies: Impacts on the French forest sector," J. For. Econ., vol. 19, no. 4, pp. 450-461, 2013.

[39] D. Adams, B. A. Mccarl, and B. C. Murray, "FASOMGHG Conceptual Structure, and Specification: Documentation," 2005.

[40] R. Hänninen and A. M. I. Kallio, "Economic impacts on the forest sector of increasing forest biodiversity conservation in Finland," Silva Fenn., vol. 41, no. 3, pp. 507-523, 2007.

[41] C. Rafal, R. C. Abt, R. Jonsson, J. P. Prestemon, and F. W. Cubbage, "Modeling the Impacts of EU Bioenergy Demand on the Forest Sector of the Southeast U.S.,” J. Energy Power Eng., vol. 7, pp. 1073-1081, 2013.

[42] A. M. I. Kallio, A. Moiseyev, B. Solberg, and a M. I. Kallio Moiseyev, A., Solberg, B., "The global forest sector model EFI-GTM. The model structure," 2004.

[43] A. Favero, R. Mendelsohn, and B. Sohngen, "Can the Global Forest Sector Survive $11^{\circ} \mathrm{C}$ Warming?," Agric. Resour. Econ. Rev., vol. 47 , no. 2, pp. $388-413$, Aug. 2018

[44] P. Schwarzbauer and E. Rametsteiner, "The impact of SFM-certification on forest product markets in Western Europe - An analysis using a forest sector simulation model," For. Policy Econ., vol. 2, no. 3-4, pp. 241-256, 2001.

[45] P. A. Samuelson, "Spatial price equilibrium and linear programming," Am. Econ. Rev., vol. 42, no. 3, pp. 283-303, 1952.

[46] A. M. I. Kallio, R. Hänninen, N. Vainikainen, and S. Luque, "Biodiversity value and the optimal location of forest conservation sites in Southern Finland," Ecol. Econ., vol. 67, no. 2, pp. 232-243, 2008.

[47] H. K. Sjølie, G. S. Latta, D. M. Adams, and B. Solberg, "Impacts of agent information assumptions in forest sector modeling," $J$. For. Econ., vol. 17, no. 2, pp. 169-184, 2011.

[48] C. M. T. Johnston and G. C. van Kooten, "Global trade impacts of increasing Europe's bioenergy demand," J. For. Econ., vol. 23, pp. $27-44,2016$.

[49] S. Caurla, F. Lecocq, P. Delacote, and A. Barkaoui, "The French Forest Sector Model: version 1.0.," 2010.

[50] J. Buongiorno, "Forest sector modeling: A synthesis of econometrics, mathematical programming, and system dynamics methods," Int. J. Forecast., vol. 12, no. 3, pp. 329-343, 1996.

[51] P. Bettinger, K. Boston, J. P. Siry, and D. L. Grebner, "Management of Forests and Other Natural Resources," For. Manag. Plan., pp. 1-20, 2017.

[52] S. M. Carvalho-Ribeiro, A. Lovett, and T. O'Riordan, "Multifunctional forest management in Northern Portugal: Moving from scenarios to governance for sustainable development," Land use policy, vol. 27, no. 4, pp. 1111-1122, Oct. 2010.

[53] G. R. Hall, "The myth and reality of multiple use forestry," Nat. Resour. J., vol. 2, pp. 276-290, 1963.

[54] Ü. Mander, H. Wiggering, and K. Helming, Multifunctional land use: Meeting future demands for landscape goods and services. Springer, 2007.

[55] MCPEF, "RESOLUTION H1 General Guidelines for the Sustainable Management of Forests in Europe," Second Minist. Conf. Prot. For. Eur. 16-17 June 1993, no. June, pp. 1-5, 1993.

[56] FAO, "FRA 2015 - Terms and Defintions," 2012.

[57] FAO, "Terms and Definitions FRA 2020," 2018.

[58] D. J. Krieger, The economic values of forest ecosystem services: a review. The Wilderness Society. 2001.

[59] TEEB, "The Economics of Ecosystems and Biodiversity: Mainstreaming the Economics of Nature: A synthesis of the approach, conclusions and recommendations of TEEB," 2010.

[60] R. Haines-Young and M. B. Potschin, "Common International Classification of Ecosystem Services (CICES) V5.1 and Guidance on the Application of the Revised Structure," 2018.

[61] G. M. Mace, K. Norris, and A. H. Fitter, "Biodiversity and ecosystem services: a multilayered relationship," Trends Ecol. Evol., vol. 27, no. 1, pp. 19-26, Jan. 2012.

[62] P. Põllumäe, H. Korjus, and T. Paluots, "Management motives of Estonian private forest owners," For. Policy Econ., vol. 42, pp. 8-14, May 2014.

[63] M. A. Côté, A. Généreux-Tremblay, D. Gilbert, and N. Gélinas, "Comparing the profiles, objectives and behaviours of new and longstanding non-industrial private forest owners in Quebec, Canada," For. Policy Econ., vol. 78, pp. 116-121, May 2017.

[64] P. Kumer and E. Štrumbelj, "Clustering-based typology and analysis of private small-scale forest owners in Slovenia," For. Policy Econ., vol. 80, pp. 116-124, Jul. 2017.

[65] M. Hugosson and F. Ingemarson, "Objectives and motivations of small-scale forest owners; theoretical modelling and qualitative assessment," Silva Fennica, vol. 38, no. 2. pp. 217-231, 2004.

[66] J. Kuuluvainen, H. Karppinen, and V. Ovaskainen, "Landowner objectives and nonindustrial private timber supply," For. Sci., vol. 42, no. 3, pp. 300-309, 1996.

[67] D. N. Wear and J. W. Coulston, "Specifying Forest Sector Models for Forest Carbon Projections," J. For. Econ., vol. 34, no. 1-2, pp. 73-97, 2019.

[68] N. J. Van Eck and L. Waltman, "VOSviewer Manual," 2018

[69] N. J. van Eck and L. Waltman, "Software survey: VOSviewer, a computer program for bibliometric mapping," Scientometrics, vol. 84 , no. 2, pp. 523-538, 2010.

[70] A. Lobianco, P. Delacote, S. Caurla, and A. Barkaoui, "The importance of introducing spatial heterogeneity in bio-economic forest models: Insights gleaned from FFSM++," Ecol. Modell., vol. 309-310, pp. 82-92, 2015.

[71] C. Petucco, A. Lobianco, and S. Caurla, "Economic Evaluation of an Invasive Forest Pathogen at a Large Scale: The Case of Ash Dieback in France," Environ. Model. Assess., 2019.

[72] S. Härkönen et al., "Environmental Modelling \& Software A climate-sensitive forest model for assessing impacts of forest management in Europe,” Environ. Model. Softw., vol. 115, no. August 2018, pp. 128-143, 2019.

[73] J. Buongiorno, S. Zhu, D. Zhang, J. Turner, and D. Tomberlin, The Global Forest Products Model. Academic, 2003.

[74] R. C. Abt, F. W. Cubbage, and Pacheco, "SOUTHERN FOREST RESOURCE ASSESSMENT USING THE SUBREGIONAL TIMBER SUPPLY (SRTS) MODEL,” For. Prod. J., vol. 50, no. 4, pp. 25-25, Apr. 2000.

[75] A. Moiseyev, B. Solberg, B. Michie, and A. M. I. Kallio, "Modeling the impacts of policy measures to prevent import of illegal wood and wood products," For. Policy Econ., vol. 12, no. 1, pp. 24-30, 2010.

[76] R. Li, J. Buongiorno, J. A. Turner, S. Zhu, and J. Prestemon, "Long-term effects of eliminating illegal logging on the world forest 
industries, trade, and inventory," For. Policy Econ., vol. 10, no. 7-8, pp. 480-490, 2008.

[77] A. Mosnier et al., "Modeling Impact of Development Trajectories and a Global Agreement on Reducing Emissions from Deforestation on Congo Basin Forests by 2030," Environ. Resour. Econ., vol. 57, no. 4, pp. 505-525, Apr. 2014.

[78] X. Zhang, B. Xu, L. Wang, A. Yang, and H. Yang, "Eliminating illegal timber consumption or production: Which is the more economical means to reduce illegal logging?," Forests, vol. 7, no. 9, 2016.

[79] P. M. Fernandes et al., "Prescribed burning in southern Europe: Developing fire management in a dynamic landscape," Frontiers in Ecology and the Environment, vol. 11, no. SUPPL. 1. 2013.

[80] A. Lobianco, S. Caurla, P. Delacote, and A. Barkaoui, "Carbon mitigation potential of the French forest sector under threat of combined physical and market impacts due to climate change," J. For. Econ., vol. 23, pp. 4-26, 2016

[81] E. Trømborg and H. K. Sjølie, "Data applied in the forest sector models NorFor and NTMIII," Ina fagrapport. Dep. Ecol. Nat. Resour. Manag. Nor. Univ. Life Sci., vol. 17, 2011.

[82] A. M. I. Kallio, O. Salminen, and R. Sievänen, "Sequester or substitute-Consequences of increased production of wood based energy on the carbon balance in Finland," J. For. Econ., vol. 19, no. 4, pp. 402-415, 2013.

[83] H. K. Sjolie, G. S. Latta, and B. Solberg, "Potentials and costs of climate change mitigation in the Norwegian forest sector - Does choice of policy matter?," Can. J. For. Res. Can. Rech. For., vol. 43, no. 6, pp. 589-598, 2013.

[84] E. H. Im, D. M. Adams, and G. S. Latta, "Potential impacts of carbon taxes on carbon flux in western Oregon private forests," For. Policy Econ., vol. 9, no. 8, pp. 1006-1017, 2007.

[85] G. Latta, D. M. Adams, R. J. Alig, and E. White, "Simulated effects of mandatory versus voluntary participation in private forest carbon offset markets in the United States," J. For. Econ., vol. 17, no. 2, pp. 127-141, 2011.

[86] F. Lecocq, S. Caurla, P. Delacote, A. Barkaoui, and A. Sauquet, "Paying for forest carbon or stimulating fuelwood demand? Insights from the French Forest Sector Model," J. For. Econ., vol. 17, no. 2, pp. 157-168, 2011.

[87] J. Buongiorno and S. Zhu, "Consequences of carbon offset payments for the global forest sector," J. For. Econ., vol. 19, no. 4, pp. 384-401, 2013.

[88] E. H. Im, D. M. Adams, and G. S. Latta, "The impacts of changes in federal timber harvest on forest carbon sequestration in western Oregon," Can. J. For. Res. Can. Rech. For., vol. 40, no. 9, pp. 1710-1723, 2010.

[89] A. M. I. Kallio, B. Solberg, L. Käär, and R. Päivinen, "Forest Policy and Economics Economic impacts of setting reference levels for the forest carbon sinks in the EU on the European forest sector," For. Policy Econ., vol. 92, no. May, pp. 193-201, 2018.

[90] A. M. I. Kallio and B. Solberg, "Leakage of forest harvest changes in a small open economy: case Norway," Scandinavian Journal of Forest Research, vol. 33, no. 5. pp. 502-510, 2018.

[91] T. Bolkesjø, E. Trømborg, and B. Solberg, "Bioenergy from the forest sector: Economic potential and interactions with timber and forest products markets in Norway," Scand. J. For. Res., vol. 21, no. 2, pp. 175-185, 2006.

[92] A. Moiseyev, B. Solberg, A. M. I. Kallio, and M. Lindner, "An economic analysis of the potential contribution of forest biomass to the EU RES target and its implications for the EU forest industries," J. For. Econ., vol. 17, no. 2, pp. 197-213, 2011.

[93] E. M. White, G. Latta, R. J. Alig, K. E. Skog, and D. M. Adams, "Biomass production from the U.S. forest and agriculture sectors in support of a renewable electricity standard," Energy Policy, vol. 58, pp. 64-74, Jul. 2013.

[94] S. Caurla, P. Delacote, F. Lecocq, and A. Barkaoui, "Stimulating fuelwood consumption through public policies: An assessment of economic and resource impacts based on the French Forest Sector Model," Energy Policy, vol. 63, pp. 338-347, 2013.

[95] H. L. Kangas, J. Lintunen, J. Pohjola, L. Hetemäki, and J. Uusivuori, "Investments into forest biorefineries under different price and policy structures," Energy Econ., vol. 33, no. 6, pp. 1165-1176, 2011.

[96] H. K. Sjølie, E. Trømborg, B. Solberg, and T. F. Bolkesjø, "Effects and costs of policies to increase bioenergy use and reduce GHG emissions from heating in Norway," For. Policy Econ., vol. 12, no. 1, pp. 57-66, 2010.

[97] J. M. Earles, A. Halog, P. Ince, and K. Skog, "Integrated Economic Equilibrium and Life Cycle Assessment Modeling for Policybased Consequential LCA," 2012.

[98] H. Böttcher, S. Frank, P. Havlík, and B. Elbersen, "Future GHG emissions more efficiently controlled by land-use policies than by bioenergy sustainability criteria," Biofuels, Bioprod. Biorefining, vol. 7, no. 2, pp. 115-125, Mar. 2013.

[99] P. Havlík et al., "Global land-use implications of first and second generation biofuel targets," Energy Policy, vol. 39, no. 10, pp. 5690-5702, 2011.

[100] S. U. Okoro, U. Schickhoff, and U. A. Schneider, "Impacts of bioenergy policies on land-use change in Nigeria," Energies, vol. 11, no. 1 , p. 152, Jan. 2018.

[101] J. K. Costanza, R. C. Abt, A. J. McKerrow, and J. A. Collazo, "Bioenergy production and forest landscape change in the southeastern United States," GCB Bioenergy, vol. 9, no. 5, pp. 924-939, May 2017.

[102] A. S. Duden et al., "Modeling the impacts of wood pellet demand on forest dynamics in southeastern United States," Biofuels, Bioprod. Biorefining, vol. 11, no. 6, pp. 1007-1029, Nov. 2017.

[103] E. Geijer, J. Andersson, G. Bostedt, R. Brännlund, and J. Hjältén, "Safeguarding species richness vs. increasing the use of renewable energy - The effect of stump harvesting on two environmental goals," J. For. Econ., vol. 20, pp. 111-125, 2014.

[104] C. Schleupner and U. A. Schneider, "Effects of bioenergy policies and targets on European wetland restoration options," Environ. Sci. Policy, vol. 13, no. 8, pp. 721-732, 2010.

[105] E. Geijer, G. Bostedt, and R. Brännlund, "Damned if you do, damned if you do not-Reduced Climate Impact vs. Sustainable Forests in Sweden," Resour. Energy Econ., vol. 33, no. 1, pp. 94-106, 2011.

[106] J. Perez-Garcia, L. A. Joyce, and A. D. McGuire, "Temporal uncertainties of integrated ecological/economic assessments at the global and regional scales," For. Ecol. Manage., vol. 162, no. 1, pp. 105-115, 2002.

[107] B. Solberg, A. Moiseyev, and A. M. I. Kallio, "Economic impacts of accelerating forest growth in Europe," For. Policy Econ., vol 5, no. 2, pp. 157-171, 2003 .

[108] R. H. Beach et al., "Climate change impacts on US agriculture and forestry: Benefits of global climate stabilization," Environ. Res. Lett., vol. 10, no. 9, 2015.

[109] G. C. van Kooten and C. Johnston, "The Economics of Forest Carbon Offsets," Ssrn, no. April, pp. 1-20, 2016.

[110] D. M. Adams, R. Alig, G. Latta, and E. M. White, "Regional Impacts of a Program for Private Forest Carbon Offset Sales," J. For., vol. 109 , no. 8, pp. 444-461, 2011.

[111] H. K. Sjølie, G. S. Latta, and B. Solberg, "Impacts of the Kyoto Protocol on boreal forest climate change mitigation," Ann. For. Sci., vol. 71, no. 2, pp. 267-277, 2014.

[112] A. Moiseyev, B. Solberg, and A. M. I. Kallio, "The impact of subsidies and carbon pricing on the wood biomass use for energy in the EU," Energy, vol. 76, pp. 161-167, 2014.

[113] M. Tavoni, B. Sohngen, and V. Bosetti, "Forestry and the carbon market response to stabilize climate," Energy Policy, vol. 35, no. 11, pp. 5346-5353, 2007.

[114] A. Favero and R. Mendelsohn, "Using Markets for Woody Biomass Energy to Sequester Carbon in Forests," J. Assoc. Environ. Resour. Econ., vol. 1, no. 1/2, pp. 75-95, 2014. 
[115] G. Latta, D. M. Adams, R. J. Alig, and E. White, "Simulated effects of mandatory versus voluntary participation in private forest carbon offset markets in the United States," J. For. Econ., vol. 17, pp. 127-141, 2011.

[116] A. M. I. Kallio, A. Moiseyev, and B. Solberg, "Economic impacts of increased forest conservation in Europe: a forest sector model analysis," Environ. Sci. Policy, vol. 9, no. 5, pp. 457-465, 2006.

[117] T. F. Bolkesjø, E. Trømborg, and B. Solberg, "Increasing forest conservation in Norway: Consequences for timber and forest products markets," Environ. Resour. Econ., vol. 31, no. 1, pp. 95-115, 2005.

[118] F. Merry, B. Soares-Filho, D. Nepstad, G. Amacher, and H. Rodrigues, "Balancing conservation and economic sustainability: The future of the amazon timber industry," Environ. Manage., vol. 44, no. 3, pp. 395-407, 2009.

[119] E. B. Barbier, N. Bockstael, J. C. Burgess, and I. Strand, "The Linkages between the Timber Trade and Tropical Deforestation???Indonesia," World Econ., vol. 18, no. 3, pp. 411-442, May 1995.

[120] L. Sun and B. E. C. Bogdanski, "Trade incentives for importers to adopt policies to address illegally logged timber: The case of non-tropical hardwood plywood," J. For. Econ., vol. 27, pp. 18-27, 2017.

[121] C. Schleupner and U. A. Schneider, "Allocation of European wetland restoration options for systematic conservation planning," Land use policy, vol. 30, pp. 604-614, 2013.

[122] D. M. Adams and G. S. Latta, "Timber trends on private lands in western Oregon and Washington: a new look," West. J. Appl. For., vol. 22, pp. 8-14, 2007.

[123] D. M. Adams and G. S. Latta, "Future Prospects for Private Timber Harvest in Eastern Oregon," WEST.J.APPL.FOR., vol. 22, no. 3, 2007.

[124] D. M. Adams and G. S. Latta, "Costs and regional impacts of restoration thinning programs on the national forests in eastern Oregon,” Can. J. For. Res., vol. 35, no. 6, pp. 1319-1330, 2005.

[125] P. J. Ince, H. Spelter, K. E. Skog, A. Kramp, and D. P. Dykstra, "Market impacts of hypothetical fuel treatment thinning programs on federal lands in the western United States," For. Policy Econ., vol. 10, no. 6, pp. 363-372, Aug. 2008.

[126] J. P. Prestemon, K. L. Abt, and R. J. Huggett, "Market impacts of a multiyear mechanical fuel treatment program in the U.S.," For Policy Econ., vol. 10, no. 6, pp. 386-399, 2008.

[127] J. A. Turner, J. Buongiorno, S. Zhu, J. P. Prestemon, R. Li, and L. S. Bulman, "Modelling the impact of the exotic forest pest Nectria on the New Zealand forest sector and its major trading partners," New Zeal. J. For. Sci., vol. 37, no. 3, pp. 383-411, 2007.

[128] C. Sun, "Timber Market Recovery after a Hurricane," For. Sci., vol. 62, no. 6, pp. 600-612, Dec. 2016.

[129] S. Caurla, S. Garcia, and A. Niedzwiedz, "Store or export? An economic evaluation of financial compensation to forest sector after windstorm. The case of Hurricane Klaus," For. Policy Econ., vol. 61, pp. 30-38, 2015.

[130] J. P. Prestemon, K. L. Abt, K. M. Potter, and F. H. Koch, "An economic assessment of mountain pine beetle timber salvage in the west," West. J. Appl. For., vol. 28, no. 4, pp. 143-153, 2013.

[131] S. K. Pattanayak et al., "Forest forecasts: Does individual heterogeneity matter for market and landscape outcomes?," For. Policy Econ., vol. 6, no. 3-4, pp. 243-260, 2004.

[132] C.-H. Yu, B. McCarl, C.-H. Yu, and B. A. McCarl, "The Water Implications of Greenhouse Gas Mitigation: Effects on Land Use, Land Use Change, and Forestry," Sustainability, vol. 10, no. 7, p. 2367, Jul. 2018.

[133] A. M. I. Kallio, "Accounting for uncertainty in a forest sector model using Monte Carlo simulation," For. Policy Econ., vol. 12, no. 1, pp. 9-16, 2010

[134] R. P. Chudy, H. K. Sjølie, and B. Solberg, "Incorporating risk in forest sector modeling - state of the art and promising paths for future research," Scandinavian Journal of Forest Research, vol. 31, no. 7. pp. 719-727, 02-Oct-2016.

[135] J. Buongiorno and C. Johnston, "Effects of parameter and data uncertainty on long-term projections in a model of the global forest sector," For. Policy Econ., vol. 93, no. May, pp. 10-17, 2018.

[136] E. O. Jåstad, W. F. Mustapha, T. F. Bolkesjø, E. Trømborg, and B. Solberg, "Modelling of uncertainty in the economic development of the Norwegian forest sector," J. For. Econ., vol. 32, no. May 2017, pp. 106-115, 2018.

[137] C. Morland, F. Schier, N. Janzen, and H. Weimar, "Supply and demand functions for global wood markets: Specification and plausibility testing of econometric models within the global forest sector," For. Policy Econ., vol. 92, pp. 92-105, Jul. 2018

[138] P. Rougieux and O. Damette, "Reassessing forest products demand functions in Europe using a panel cointegration approach," Appl. Econ., vol. 50, no. 30, pp. 3247-3270, 2018.

[139] A. Kallio, B. Solberg, A. M. I. Kallio, and B. Solberg, "On the Reliability of International Forest Sector Statistics: Problems and Needs for Improvements," Forests, vol. 9, no. 7, p. 407, Jul. 2018.

[140] E. Trømborg, T. F. Bolkesjø, and B. Solberg, "Impacts of policy means for increased use of forest-based bioenergy in Norway-A spatial partial equilibrium analysis," Energy Policy, vol. 35, no. 12, pp. 5980-5990, 2007.

[141] Y. Cai, D. Newth, J. Finnigan, and D. Gunasekera, "A hybrid energy-economy model for global integrated assessment of climate change, carbon mitigation and energy transformation," Appl. Energy, vol. 148, pp. 381-395, Jun. 2015.

[142] V. Bosetti et al., "Change Hybrud Model WITCH A World Induced Technical Change Hybrid Model Emanuele Massetti," JSTOR, 2005 .

[143] J.-C. Hourcade, M. Jaccard, C. Bataille, and F. Ghersi, "Hybrid Modeling: New Answers to Old Challenges Introduction to the Special Issue of The Energy Journal," Energy J., vol. SI2006, no. 01, 2011.

[144] N. Shabani, S. Akhtari, and T. Sowlati, "Value chain optimization of forest biomass for bioenergy production: A review," Renewable and Sustainable Energy Reviews, vol. 23. pp. 299-311, 2013.

[145] A. De Meyer, D. Cattrysse, J. Rasinmäki, and J. Van Orshoven, "Methods to optimise the design and management of biomass-forbioenergy supply chains: A review," Renewable and Sustainable Energy Reviews, vol. 31. pp. 657-670, 2014.

[146] P. J. Ince et al., "U.S. Forest Products Module: A Technical Document Supporting the Forest Service 2010 RPA Assessment," 2011.

[147] B. Peter and K. Niquidet, "Estimates of residual fibre supply and the impacts of new bioenergy capacity from a forest sector transportation model of the Canadian Prairie Provinces," For. Policy Econ., vol. 69, pp. 62-72, 2016.

[148] K. Niquidet and D. Friesen, "Bioenergy potential from wood residuals in Alberta: a positive mathematical programming approach," Can. J. For. Res., vol. 44, no. 12, pp. 1586-1594, 2014.

[149] C. S. Galik and R. C. Abt, "Sustainability guidelines and forest market response: an assessment of European Union pellet demand in the southeastern United States," GCB Bioenergy, vol. 8, no. 3, pp. 658-669, May 2016.

[150] G. S. Latta, J. S. Baker, and S. Ohrel, “A Land Use and Resource Allocation (LURA) modeling system for projecting localized forest CO2effects of alternative macroeconomic futures," For. Policy Econ., vol. 87, no. October 2017, pp. 35-48, 2018.

[151] J. Perez-Garcia, L. A. Joyce, C. S. Binkley, and A. D. McGuire, "Economic impacts of climatic change on the global forest sector: An integrated ecological/economic assessment," Crit. Rev. Environ. Sci. Technol., vol. 27, no. SPEC. ISS., pp. S123-S138, 1997.

[152] L. O. Eriksson et al., "Climate change mitigation through increased wood use in the European construction sector-towards an integrated modelling framework," Eur. J. For. Res., vol. 131, no. 1, pp. 131-144, 2012.

[153] S. Caurla, V. Bertrand, P. Delacote, and E. Le Cadre, "Heat or power: How to increase the use of energy wood at the lowest cost?," 
Energy Econ., vol. 75, pp. 85-103, Sep. 2018.

[154] T. Beaussier, S. Caurla, V. Bellon-Maurel, and E. Loiseau, "Coupling economic models and environmental assessment methods to support regional policies: A critical review," J. Clean. Prod., vol. 216, pp. 408-421, Apr. 2019.

[155] L. Sievanen, L. M. Campbell, and H. M. Leslie, "Challenges to Interdisciplinary Research in Ecosystem-Based Management," Conserv. Biol., vol. 26, no. 2, pp. 315-323, 2012.

[156] L. M. Campbell, "Diversity Overcoming Obstacles to Interdisciplinary Research," Conserv. Biol., vol. 19, no. 2, pp. 574-577, 2005.

[157] L. Tardieu and L. Tuffery, "From supply to demand factors: What are the determinants of attractiveness for outdoor recreation?," Ecol. Econ., vol. 161, pp. 163-175, 2019.

[158] G. S. Latta, J. S. Baker, and S. Ohrel, "A Land Use and Resource Allocation (LURA) modeling system for projecting localized forest CO2effects of alternative macroeconomic futures," For. Policy Econ., vol. 87, pp. 35-48, 2018.

[159] K. M. A. Chan, T. Satterfield, and J. Goldstein, "Rethinking ecosystem services to better address and navigate cultural values," Ecological Economics, vol. 74. Elsevier, pp. 8-18, 01-Feb-2012.

[160] L. An, "Modeling human decisions in coupled human and natural systems : Review of agent-based models," Ecol. Modell., vol. 229, pp. 25-36, 2012.

[161] S. Heckbert, T. Baynes, and A. Reeson, "Agent-based modeling in ecological economics," Ann. N. Y. Acad. Sci., vol. 1185, pp. 3953,2010

[162] M. Janssen and E. Ostrom, "Empirically Based, Agent-based models," Ecol. Soc., vol. 11, no. 2, 2006.

[163] J. Pohjola, J. Laturi, J. Lintunen, and J. Uusivuori, "Immediate and long-run impacts of a forest carbon policy-A market-level assessment with heterogeneous forest owners," J. For. Econ., vol. 32, pp. 94-105, Aug. 2018.

[164] R. Yousefpour, A. L. D. Augustynczik, C. P. O. Reyer, P. Lasch-Born, F. Suckow, and M. Hanewinkel, "Realizing Mitigation Efficiency of European Commercial Forests by Climate Smart Forestry," Sci. Rep., vol. 8, no. 1, pp. 1-11, 2018.

[165] G. A. Mendoza and H. Martins, "Multi-criteria decision analysis in natural resource management: A critical review of methods and new modelling paradigms," Forest Ecology and Management, vol. 230, no. 1-3. Elsevier, pp. 1-22, 15-Jul-2006. 


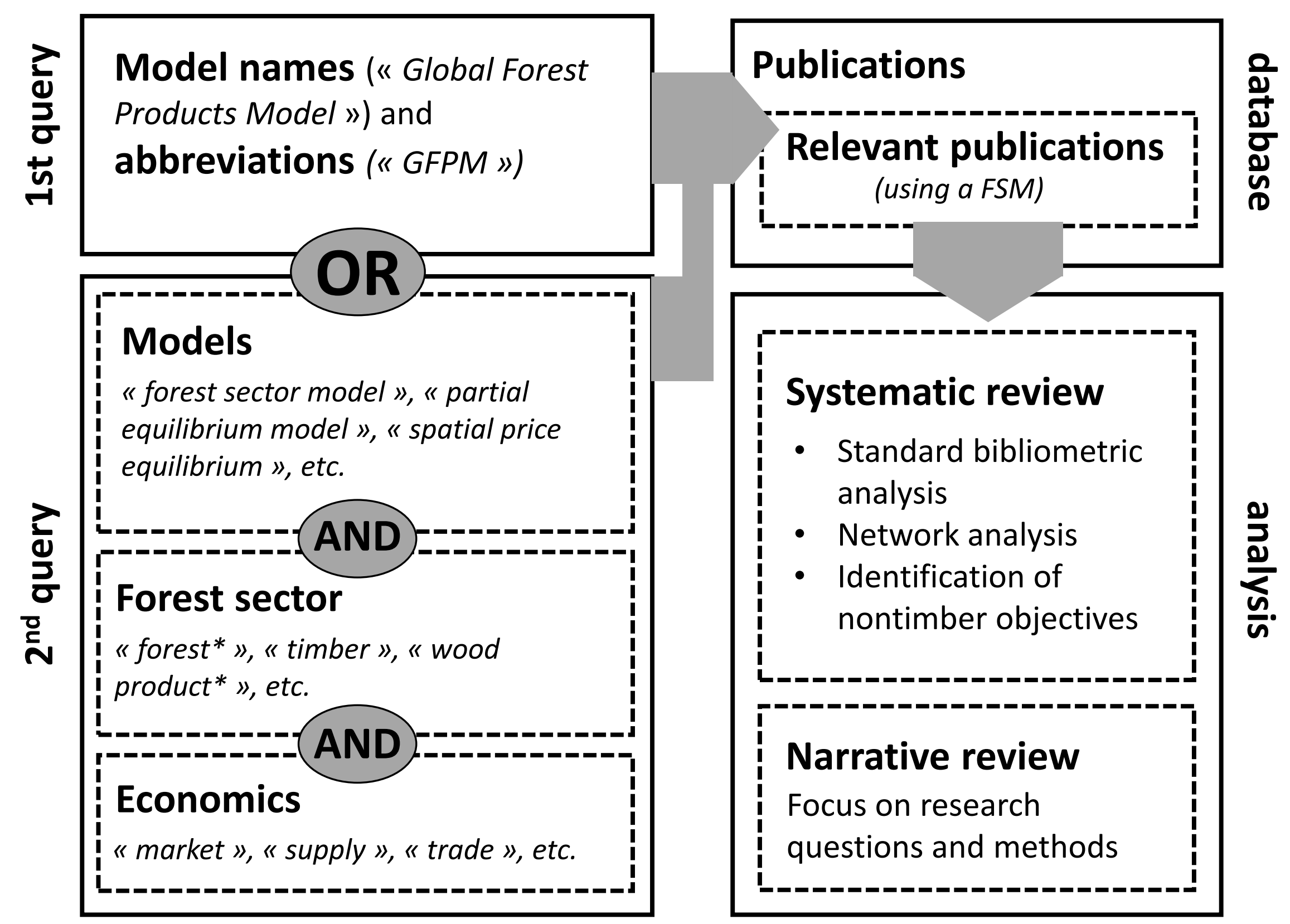




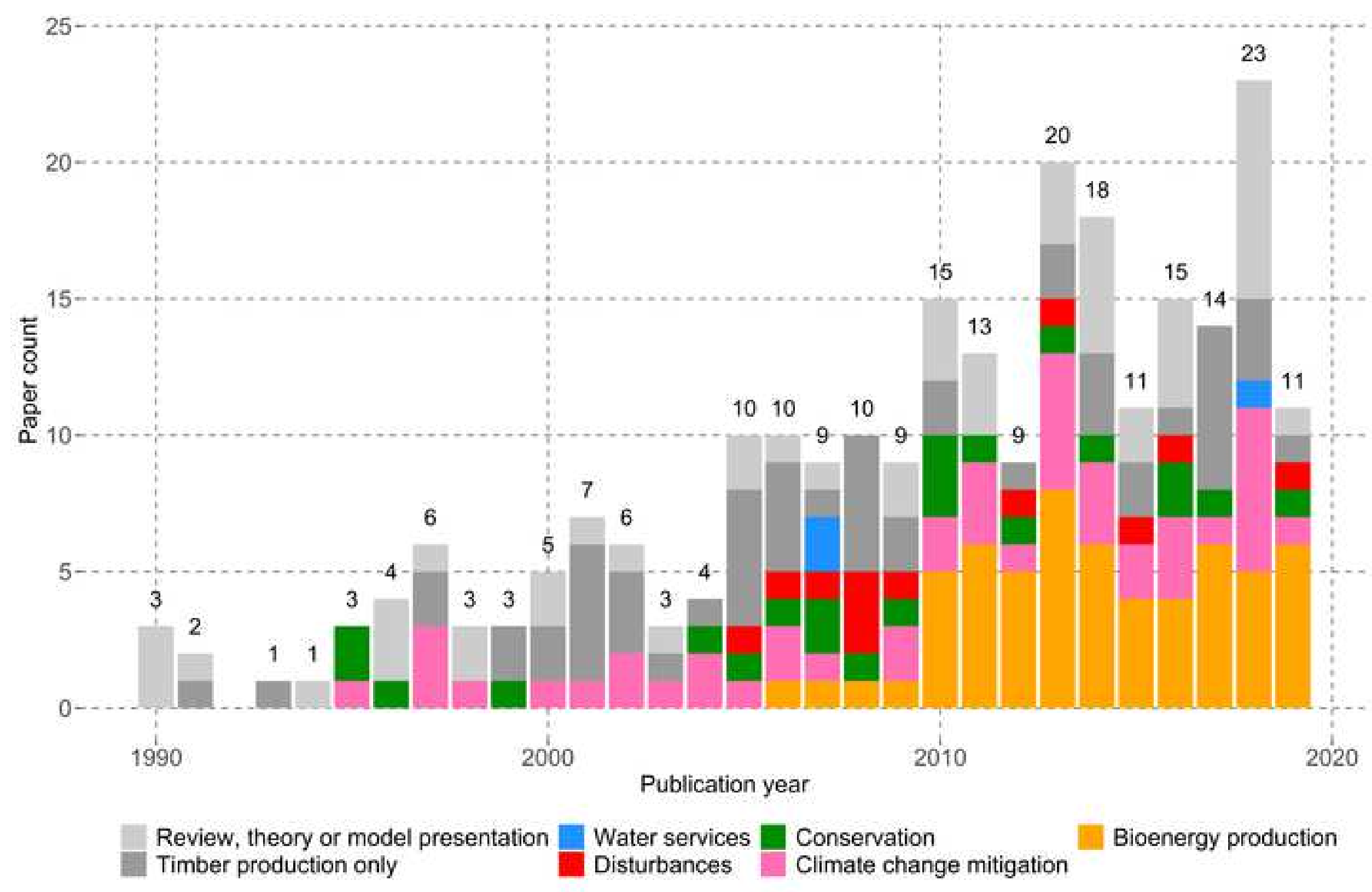



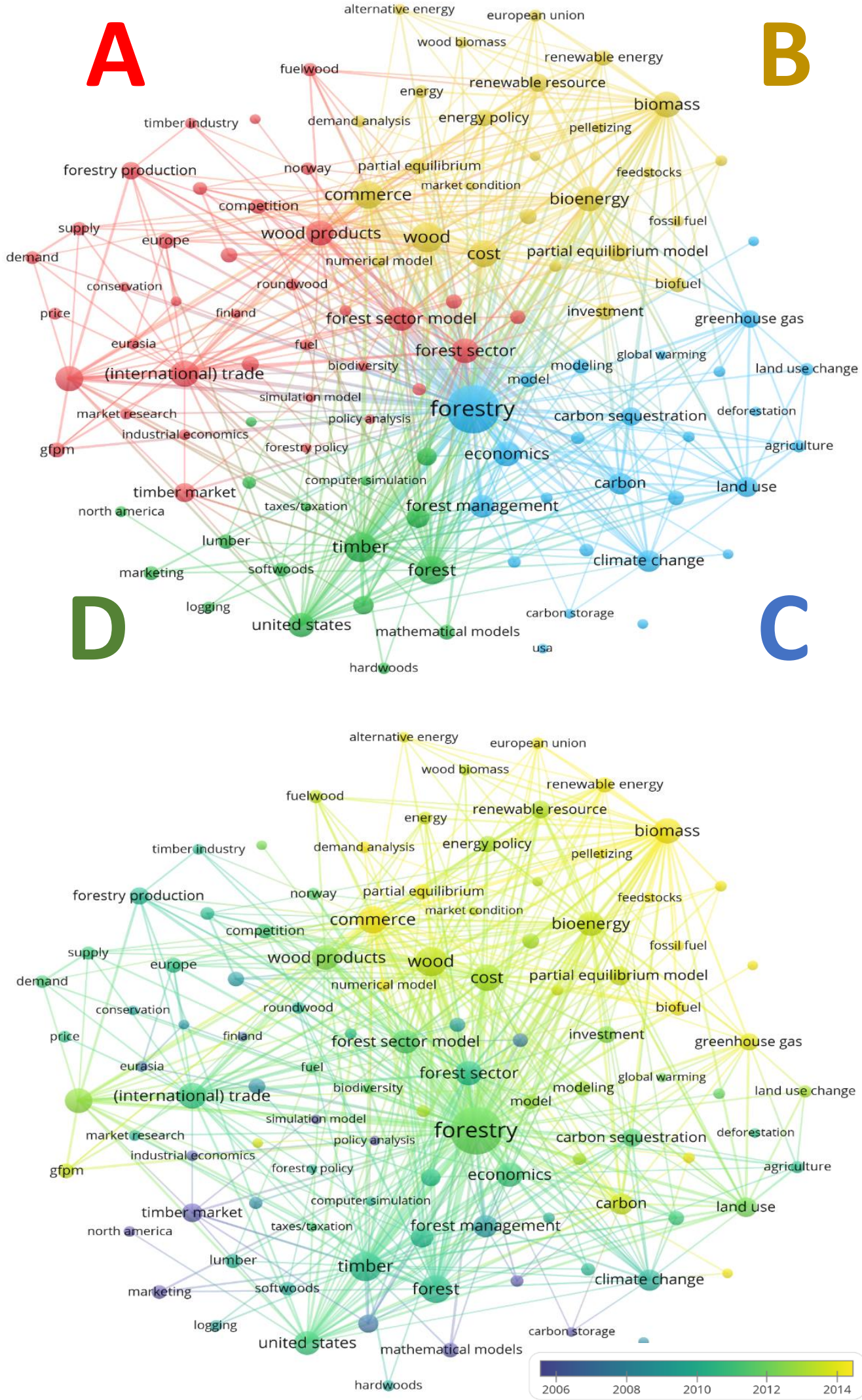